\title{
Diversion In Children Criminal Justice System Through Restorative Justice
}

\author{
Yudi Hendarto ${ }^{1}$ and Umar Ma'ruf ${ }^{2}$
}

Abstract. The formulation of the problem and the purpose of this study is to describe and analyze the diversion urgency in handling juvenile criminal cases, and to describe and analyze Perma No. 4 of 2014 on Diversion in criminal matters menyelesaian children through restorative justice approach. This research method using normative legal research methods dengn type of research is descriptive analytical. Based on the analysis result No. 4 of 2014 can be presented the following results, that Perma No. 4 of 2014 is needed in handling juvenile criminal cases. This is because during this time the condition of children who are in the coaching institutions, detention and permayarakatan far worse than a face appeared positive aspects of child development. Mixing children with adults in penitentiary have negative effects and its own psychological burden for the child, because he considered himself the same as adults with Perma No. 4 of 2014.

Keywords: Diversion, Child Criminal Justice System, Restorative Justice

\section{Introduction}

A child by their very nature are generally still have the power of reason that has not been good enough to distinguish the good things and bad. Criminal acts by children in general is a process of imitating or affected by the environmental behavior patterns because childhood is the period of the formation of character, personality, and character of a human being. Indonesia as a state party to the Convention on the Rights of the Child (Convention on the Right of the Child), which regulates the principles of the legal protection of children, is obliged to provide special protection to children in conflict with the law. One form of protection of children by the state is realized through special criminal justice system for children in conflict with the law.

Juvenile justice system by Yahya Harahap is a control system of the delinquency (juvenile delinquency), which consists of institutions dealing with the investigation of children, child investigation, prosecution of children, juvenile justice and correctional children. ${ }^{3}$ While the juvenile justice system are all elements related to the criminal justice system in handling cases of delinquency. First, the police as a formal institution when the brat first touch justice system, which will also determine whether the child would be released or processed further. Second, prosecutors and parole agencies will also determine whether the child would be released or processed to juvenile justice. Third, the juvenile court, the stage when the child will be placed in the choices, ranging from freed up to be included in the institution of punishment. The latter institution condemnation. 4

Legal protection for children can be performed as a legal protection of the child also include interests related to the welfare of children. Protection of children in conflict

\footnotetext{
${ }^{1}$ Student of Masters (S2) of Law Faculty of Law Unissula Semarang and Head of the State Prosecutor's Office of Kendal email: numana.iphone7@icloud.com

${ }^{2}$ Lecturer of Faculty of Law UNISSULA Semarang

${ }^{3}$ Abintoro Prakoso 2013 Pembaruan Sistem Peradilan Pidana Anak Laksbang Grafika Yogyakarta p. 142

${ }^{4}$ Ibid.
} 
with the law, is the shared responsibility of law enforcement officers. Not only children as perpetrators, but covers also children who are victims and witnesses. Law enforcement officers involved in handling children in conflict with the law in order not only refer to the Act No. 11 of 2012 tentan Criminal Justice System Children (SPPA Act) or regulations of other legislation relating to the treatment of children in conflict by law, but prefers peace than the formal legal process that came into effect two (2) years after the law was enacted SPPA or August 1, 2014 (Article 108 of SPPA Act).

The Supreme Court responded very quickly SPPA Act. Chairman of the Supreme Court Muhammad Hatta Ali signed the Regulation of the Supreme Court (Perma) No. 4 of 2014 on Guidelines for Diversion in the Criminal Justice System Son even before the government regulation which is derived from SPPA Act issued. The Perma important points that the judge should resolve the issue of children in conflict with the law by way of diversion which is a legal procedure which is still very new in the system and criminal law reform in Indonesia. Besides, it also, Perma contains procedures for the diversion of the grip judges in juvenile criminal settlement considering regulation contains no special procedural law Criminal Justice System Children's diversion.

According to Article 5 of SPPA Act, Child Criminal Justice System shall prioritize restorative justice approach that includes (paragraph 2): (a) the investigation and criminal prosecution of children carried out in accordance with the provisions of the legislation, unless otherwise provided in this Act; (B) the hearing of children by a court in the general court; and (c) coaching, mentoring, supervision and / or assistance during the implementation process and after a criminal or a sentence or action. Children in the Criminal Justice System as referred to in paragraph (2) letter $a$ and $b$ must be pursued diversion. Understanding diversion stated in Article 1 (7) of the SPPA, namely the transfer of the settlement of the child to the criminal justice process outside the criminal justice process.

Diversion is a new tool that is offered in the juvenile justice by promoting well-being and balance also felt able to create efficiency justice in Indonesia. With the existence of this mechanism is expected to emerge three (3) benefits, namely: (1) children who commit criminal acts to avoid the negative effects of detention and imprisonment; (2) has been found to completion more useful for the recovery of victims; and (3) increasing public awareness through community leaders to guide, not stigmatize children who commit the crime. ${ }^{5}$

Principally through SPPA Act has approach is keadila restorative (restorative justice) and the diversion as efforts to resolve criminal offenses committed by children, so that the application of restorative justice will offer answers to important issues in the resolution of criminal matters, namely: (1) criticism the judicial system that does not provide an opportunity especially for the victim (criminal justice system that disempowers individual); (2) eliminate the conflict, especially between the perpetrator to the victim and the community; and (3) the fact that the feeling of helplessness experienced as a result of a criminal act must be overcome to achieve an improvement (in orderto achievereparation). ${ }^{6}$

\footnotetext{
${ }^{5}$ Putri Kusuma Amanda 2014 AQJ dan Peradilan Pidana Anak Kompas Jakarta.

${ }^{6}$ Ivo Aersten et.al. 2011 Restorative Justice and The Active Victim: Exploring the Concept of Empowerment TEMIDA Journal.
} 
As a system, as defined in Article 1 of the SPPA Act, which includes institutions ranging inquiry stage up to the stage after undergoing criminal coaching, synergy between the institutions that sustain the process of juvenile justice is important and determine the successful implementation restotarif justice models. One of the problems that arise when the jurisdiction is the absence of government regulations as mandated by SPPA Act which regulates the implementation of diversion. It resulted in the level of implementation in the field related to the duties and models of inter-agency coordination in carrying out the process and the results of the diversion agreement in the juvenile justice system.

Based on the foregoing, the authors determine the formulation of the problem to be discussed in this paper are: Is the diversion of urgency in handling juvenile criminal cases?; How Perma No. 4 of 2014 on Diversion in criminal matters menyelesaian children through restorative justice approach?

\section{Research Methods}

The method used in this study is a normative legal research methods focusing on the inventory of positive law, principles and legal doctrine, legal discovery in the case in concreto, systematic law, the level of synchronization of law, comparative law and legal history. ${ }^{7}$ Peter M Marzuki in his book Legal Research, states that legal research is the process of finding the rule of law, principles of law, and the legal doctrines in order to address the legal issues at hand. ${ }^{8}$

While the type of research used in this study is a descriptive analysis, which is intended to give the data as accurately as possible about a situation or other symptoms. ${ }^{9}$ The term implies analytical grouping, connect, compare, and give meaning or definition of the actions chosen, descriptive data were collected for analysis as a basis to be able to solve problems that arise.

\section{Results And Discussion}

\subsection{Urgency Diversion In Criminal Case of Children Handling}

The fact the lack of attention to the problems of children in conflict with the law can also be seen in children are imprisoned, some of them even had to be placed together with adult prisoners thereby increasing the likelihood of children becoming victims of violence, abuse and torture of adults. ${ }^{10}$ It is also related to the lack of judicial system in Indonesia that offer an alternative to resolve the criminal case of children.

The judicial process will be conducive to the main interests of the child and will be conducted in an atmosphere of understanding, which will allow the child to participate in it and express themselves freely. Having the right represented by legal counsel or invoke legal assistance free of charge. Parents or guardians are entitled to participate

\footnotetext{
${ }^{7}$ Soerjono Soekanto dan H.Abdurrahman 2003 Metode Penelitian Hukum Rineka Cipta Jakarta p. 56.

${ }^{8}$ Peter Mahmud Marzuki 2005 Penelitian Hukum Kencana Prenada Media Group Jakarta p. 35.

${ }^{9}$ Bambang Sugono 2003 Metodologi Penelitian Hukum Raja Grafindo Persada Jakarta p. 10

${ }^{10}$ Ibid.
} 
in the proceedings and may be required by the authorities to attend for the sake of the child. ${ }^{11}$

In the national positive law, regulation on the protection of children and methods of settlement of criminal cases committed by children can be seen from the constitution of this country. In Article 28 B (2) of the 1945 Constitution states that every child has the right to live, grow and develop and are entitled to protection from violence and discrimination. While in the level of the Act, regulations on child protection and juvenile settlement method can be seen one of them in Act No. 11 of 2012 tentan Child Criminal Justice System (SPPA Act).

SPPA Act is one of the reform of sentencing in Indonesia for in the legislation contains the detention period is shorter and also promote the efforts of surety and regulates the obligations of law enforcers to seek diversion (settlement through non-formal) at all stages of the legal process. Diversion is the diversion of children from the settlement of the criminal justice process to outside the criminal justice process. Thus, children who were arrested still got a chance to not be imprisoned and still be able to menlanjtkan education or work.

Based on the foregoing, it is very important diversion in handling juvenile criminal cases.

\subsection{Perma No. 4 of 2014 on Diversion In Solving Criminal Case of Children Through Restorative Justice Approaches}

The law governing the protection of children and methods of settlement of the criminal case of children, among others, Act No. 4 of 1979 on Child Welfare, Act No. 39 of 2009 on Human Rights, Act No. 23 of 2002 on Child Protection and Act No. 3 of 1997 on Juvenile Court which was later updated with Act No. 11 of 2012 on Juvenile Justice System (SPPA Act).

Renewal Act No. 3 of 1997 to the SPPA Act is because of the shape of the legal needs of the community that comprehensively provides protection to children in conflict with the law have not been met by Act No. 3 of 1997, which is the paradigm of restorative justice or may be called justice restorative. Article 1 (6) of the SPPA explained that restorative justice is the completion of the criminal case involving the perpetrator, the victim, the perpetrator's family / victim, and other relevant parties to work together to find a fair settlement with the emphasis on restoring back to the original condition, and not retaliation. Restorative justice not only provide an alternative to prosecution and imprisonment,

The provisions concerning the diversion is then set in Perma No. 4 of 2014 on Diversion. This means that Perma is the result of the development of restorative justice system that began in Indonesia. The purpose of the enactment of the Perma is that judicial efficiency can occur in Indonesia, especially on children in conflict with the law who should get more attention, and still consider welfare. It is also able to see the state's responsibility in the maintenance of children in conflict with the law.

Article 1 (1) Perma No. 4 of 2014 states regarding the diversion of government is to seek the implementation of the completion of the criminal case that consensual

\footnotetext{
${ }^{11}$ Purniati et.al. 2004 Analisa Situasi Sistem Peradilan Pidana Anak (Juvenile Justice System) di Indonesia Unicef Jakarta p.30.
} 
deliberations through restorative justice approach involving the child and parent / guardian, victim and / or parent / guardian, the supervising social, professional social workers, community representatives and the parties involved in the other. There are three basic principles that form of restorative justice, namely: ${ }^{12}$

- Of recovery to those who suffered losses due to crime;

- Performers have the opportunity to be involved in the restoration of the state; and

- The Court acts to maintain public order and community acted to preserve the peace that is fair.

Of the three basic principles, it is known that restorative justice will provide feedback for the offender, the victim and the people involved in it. In the justice retoratif also allow for imprisonment if such sanctions are the demands of the victims and it is considered that by doing such penalties are considered perpetrators accountable for their actions.

\section{Closing}

\subsection{Conclution}

- The lack of legal protection of children in conflict with the law makes the diversion as a very important thing in handling juvenile criminal cases. The condition of the children who are in the coaching institutions, detention and permayarakatan far worse than a face appeared positive aspects of child development. Mixing children with adults in penitentiary have negative effects and its own psychological burden for the child, because he considered himself the same as adults.

- Perma No. 4 of 2014 is the result of the development of restorative justice system that began in Indonesia. The purpose of the enactment of the Perma is that judicial efficiency can occur in Indonesia, especially on children in conflict with the law who should get more attention, and still consider welfare. It is also able to see the state's responsibility in the maintenance of children in conflict with the law. Through Perma government is working on the implementation of the completion of the criminal case that consensual deliberations through restorative justice approach involving the child and parent / guardian, victim and / or parent / guardian, the supervising social, professional social workers, community representatives and the parties involved more.

\subsection{Suggestion}

- For the Government to immediately issue a government regulation as implementing regulations for SPPA Act.

- For law enforcement agencies to pay more attention to Perma No. 4 of 2014 in handling juvenile criminal cases.

\footnotetext{
${ }^{12}$ M.Taufik Makarao op.cit. p. 33
} 


\section{Bibliography}

[1] Abintoro Prakoso 2013 Pembaruan Sistem Peradilan Pidana Anak Laksbang Grafika Yogyakarta.

[2] Bambang Sugono 2003 Metodologi Penelitian Hukum Raja Grafindo Persada Jakarta.

[3] Ivo Aersten et.al. 2011 Restorative Justice and The Active Victim: Exploring the Concept of Empowerment Journal TEMIDA

[4] Peter Mahmud Marzuki 2005 Penelitian Hukum Kencana Prenada Media Group Jakarta.

[5] Purniati et.al. 2004 Analisa Situasi Sistem Peradilan Pidana Anak (Juvenile Justice System) di Indonesia Unicef Jakarta.

[6] Putri Kusuma Amanda 2014 AQJ dan Peradilan Pidana Anak Kompas Jakarta.

[7] Suryono Soekanto dan H.Abdurrahman 2003 Metode Penelitian Hukum Rineka Cipta Jakarta.

[8] M.Taufik Makarao et.al. Desember 2013 Pengkajian Hukum Tentang Penerapan Restorative Justice Dalam Penyelesaian Tindak Pidana yang Dilakukan Oleh Anakanak Laporan Diskusi Badan Pembinaan Hukum Nasional Kementrian Hukum dan HAM RI Jakarta.

[9] RI the Act of 1945.

[10] The Code of Criminal Law.

[11] RI Act No. 3 of 1997 on Juvenile Court.

[12] RI Act No. 11 of 2012 on the Criminal Justice System Child.

[13] RI Perma No. 4 of 2014 on Diversion.

[14] RI Act No. 12 of 2011 Concerning the Establishment of Legislation.

[15] RI the Supreme Court Regulation No. 2 of 2012 on Limitation Adjustment light crime and the amount of penalties in the Criminal Code. 